\title{
Genesis of Miocene litho-stratigraphic trap and hydrocarbon accumulation in the Qiongdongnan Basin, northern South China Sea
}

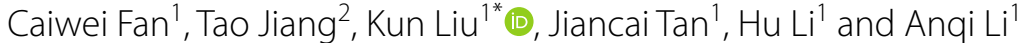

\begin{abstract}
In recent years, several large gas fields have been discovered in western Qiongdongnan Basin. It is important and necessary to illustrate their sedimentary characteristics and hydrocarbon migration so that more gas fields could be discovered in the future. Previous regional tectonic-sedimentary researchers show that large-scale source rock of the Yacheng Formation developed in the Ledong and Lingshui sags due to the Red River Fault pull-apart strike slip in early Oligocene. The main targets for hydrocarbon exploration in this area are the Miocene deep water reservoirs. In late Miocene, the Huangliu Formation reservoirs are composed of the early channels which were sourced by river systems in Hainan uplift and the consequent channels were sourced by Qiupen River in Kunsong uplift. Both axial channels exhibit unique spatial distribution patterns and geometries. The other kind of reservoir developed in the middle Miocene Meishan Formation, which compose of slope break-controlled submarine fan. They can be further classified into three types - slope channelized fan, basin floor fan, and bottom current reworked fan. The various fans have different reservoir quality. These two kinds of reservoirs contribute to four types of litho-stratigraphic traps under the actions of sedimentation and subsidence. The overpressure caused by hydrocarbon generation can fracture deeper strata and result in regional fractured network for hydrocarbon migration. Therefore, free gas driven by overpressure and buoyancy force can be migrated into Miocene litho-stratigraphic traps to accumulate. The revealed genesis of Miocene lithologic trap and hydrocarbon accumulation in the Qiongdongnan Basin would greatly contribute to the further hydrocarbon exploration in northern South China Sea and can be helpful for other deep water areas around the world.
\end{abstract}

Keywords: Qiongdongnan Basin, Ledong sag, Lingshui sag, Axial channel, Submarine fan, Litho-stratigraphic trap, Overpressure, Hydrocarbon accumulation

\section{Introduction}

Qiongdongnan basin is a Cenozoic petroliferous extensional basin which is located in the continental margin of the northern South China Sea and southeast of the Hainan Island. It stretches northeastward with alternating depressions and uplifts framework and can be subdivided into northern depression, middle uplift zone, middle depression, and south uplift zone, including 10 sub-depressions, such as Yannan sag, Yabei sag, Ledong sag, Lingshui sag, and so on (Fig. 1). The Ledong and

\footnotetext{
*Correspondence: liukun1@cnooc.com.cn

1 Zhanjiang Branch of CNOOC Ltd., Zhanjiang 524057, Guangdong, China Full list of author information is available at the end of the article
}

Lingshui Sags are the two largest sags in the Qiongdongnan Basin, characterized by deep burial strata, thick deposition, high temperature, and overpressure (Xie et al. 2006; Pettingill and Weimer 2002). However, the hydrocarbon exploration potential in these two sags was not considered to be promising for a long time due to three reasons. Firstly, the resource potential was quite uncertain. Limited by poor seismic data in the past, the scale and distribution of Oligocene source rock (the Yacheng Formation) could not be clearly identified. Secondly, fault activity in most regions was absent or resting since Neocene. Possibility and efficiency of hydrocarbon vertical migration were dubious. Thirdly, owing to a lack of well and 3D seismic data, there were enormous controversies 


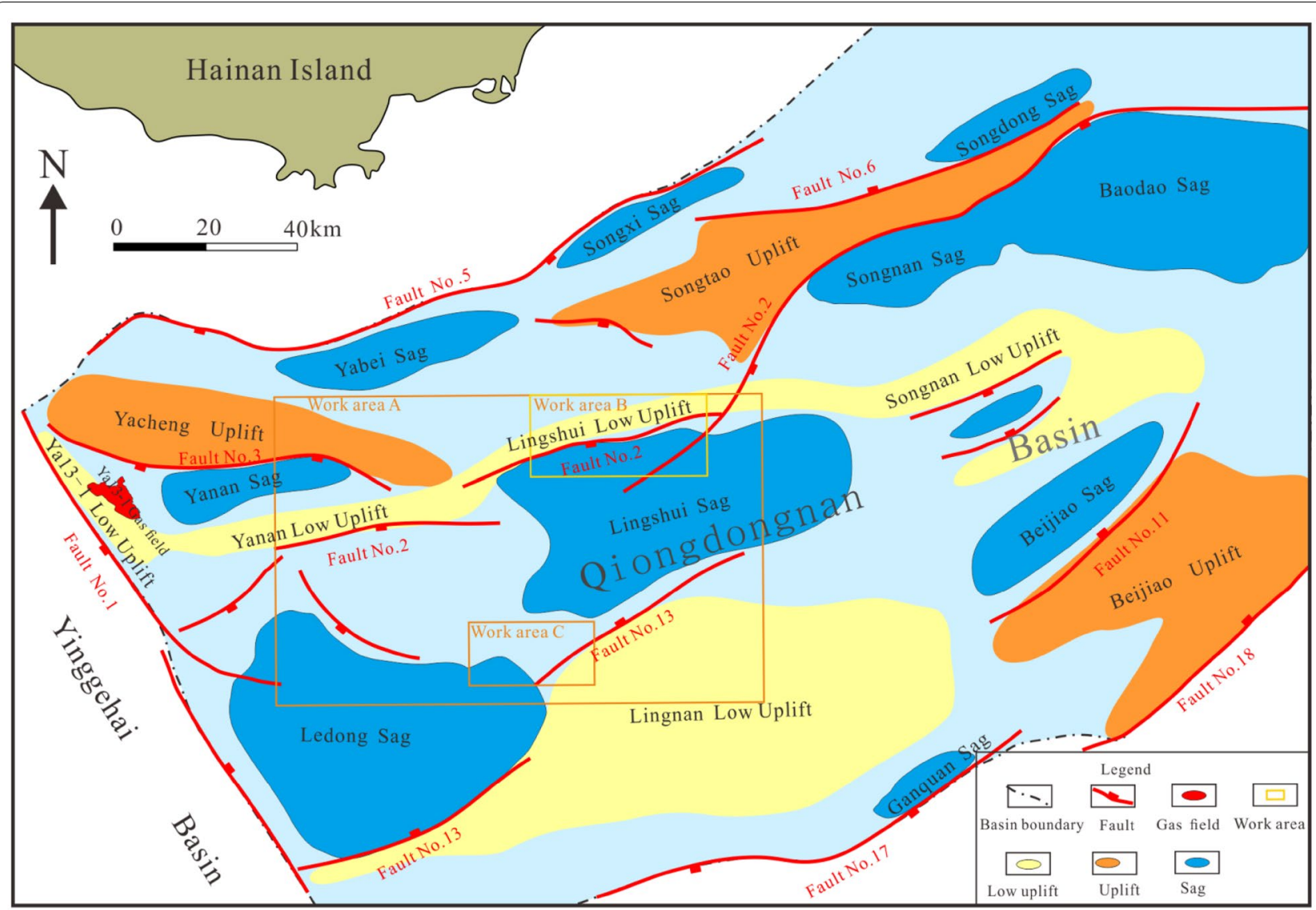

Fig. 1 Tectonic division in the Qiongdongnan Basin

on provenance, formation mechanism, and reservoir spatial distribution of axial channels (Antbreh and Krastel 2006; Su et al. 2013; Xu et al. 2012; He et al. 2011). The shortage of basic geological information restricted the understanding of the petroleum system in western Qiongdongnan Basin. Moreover, exploration confidence in this field was severely defeated by all failures in well drilling in the past.

In recent several years, large-scale high-quality 3D seismic acquisition and application, including the widespread application of pre-stack depth migration in slope break belt, make it possible to identify and evaluate Paleogene the Yacheng Formation as source rock, which is also favorable for Miocene seismic sedimentology, paleotopography, and sedimentation researches. With the help of high-resolution electric image logging technology, sedimentary textures associated with reservoir formation environment can be clearly identified. Moreover, this study conducted the pressure-accumulation relation research and description of fracture net which can be served as vertical migration paths. Research results illustrate reservoir-forming mechanism using new 3D data and advanced imaging logging technology, which is helpful for gas exploration and leads to the recent breakthrough of gas exploration in this area, such as LS25 gas field and LS13 gas field.

\section{Geological background}

The Ledong and Lingshui Sags are located in southwestern Qiongdongnan Basin, northern South China Sea. The Ledong sag is bounded by Zhongjian uplift, like an irregular square narrows eastward, while Lingshui sag is similar to a narrow irregular trapezoid (Fig. 1). The extension amount in the Ledong sag can reach up to $138 \mathrm{~km}$, comparing to $20 \mathrm{~km}$ that of the Lingshui sag. The Ledong sag is a graben controlled by northern Fault No. 2 and southern Fault No. 13. As contrasted to larger fault throw of Fault No. 13, Fault No. 2 exhibits remarkable segmented activity and fault throw is generally small. The western Lingshui sag features a graben, while its eastern part is a half-graben with gentle-slope and fault terrace which faults in the south and overlaps in the north (Zhao et al. 2010; Lei et al. 2011). It is the variation of tectonic stress from east to west that resulted in the different 
extension amount between two sags. Early Oligocene was the critical period for the development of source rock, when the Ledong sag was controlled by Red River Fault (Fault No. 1), which had a large component of extension amount owing to pull-apart strike-slip processes at that time (Chen et al. 1996; Tapponnier et al. 1990). So it can be inferred that source rock in the Ledong sag would be thicker and larger than that in the Lingshui sag in the view of tectonic-stratigraphic evolution.

At present, although there is no well drilled into the Oligocene in the Ledong and Lingshui sags, carbon isotope characteristics of gas in the Huangliu Formation from the Ledong and Lingshui sags is similar to those from the Yacheng 13-1 gas field, whose gas source has been proven to be from coal measures in the Yacheng Formation (Xie and Tong 2011). Recent acquired 3d seismic data allow us to better understanding the sequence stratigraphy in the area. Seismic stratigraphic correlation shows the super-thick early Oligocene (the Yacheng Formation) developed in the Ledong and Lingshui sags, while the Eocene is only restricted to subsidence centers, and its range of distribution gradually decreases from north to south. On the contrary, Oligocene Yacheng Formation becomes thicker northward, which is coincident with the extensional pattern in western Qiongdongnan Basin. These findings differ from previous researches, which assumed that Eocene and early Oligocene in the Ledong and Lingshui sags were mainly neritic environment (Zhu et al. 2008; Gong and Li 2004).

It can be inferred that in the Yacheng Formation the terrain sloped gently in the Ledong and Lingshui sags from the fact that the thickness of the Yacheng Formation is relatively even in western basin and depocenters are not obvious. This paleogeomorphology is similar to the nearby Yannan sag, which is not only favorable for the development of marine-terrestrial transitional sediment-coal measures, but also for the concentration of high organic matter due to semi-closed neritic environment that spread widely like a ribbon in the central Ledong and Lingshui sags (Mi et al. 2010; Liu et al. 2011; $\mathrm{Li}$ et al. 2011). The distribution of the Yacheng Formation with $2000 \mathrm{~m}$ thick is over $5300 \mathrm{~km}^{3}$ in the Ledong sag, while that with the similar thickness in the Lingshui sag is about $3900 \mathrm{~km}^{2}$. The mean TOC (total organic carbon) of the Yacheng coal layers in the Yanan sag is approximately $20 \%$. The carbonaceous mudstone has the average TOC of $5 \%$, and coal layers developed as a form of thin interbeds. Kerogen type of the Yacheng source rock is humic (type III) and gas generation is predominant. Huge total thickness and continuous hydrocarbon-generating ability of the source rock make up for the deficiency of thin coal layers.

\section{Reservoir and litho-stratigraphic trap characteristics}

The hydrocarbon explorations in this area have documented two kinds of reservoirs: one is axial channels developed in the Late Miocene Huangliu Formation and the other is the Middle Miocene submarine fans in the Meishan Formation.

\section{Provenance of axial channels in Huangliu Formation}

The axial channels in Huangliu Formation are distributed in the central part of the whole basin. The early axial channels developed mainly in northern Ledong sag, while the later channels spread from eastern Ledong sag to Lingshui sag and further east.

During late Miocene, the Yinggehai Basin and Qiongdongnan Basin began to combine into one sedimentary assemblage, developing a great number of channels along the long axis of basin (Lin et al. 2011a, b). There are three kinds of perspectives on the provenance system of these channels: (1) red river system from the north of the Yinggehai Basin (Wang et al. 2011; Yuan et al. 2010a, b), (2) river system from Indo-China peninsula (east coast of Vietnam) (Yao et al. 2008), and (3) river system originated from eastern the Yinggehai Basin (Wu and Qin 2009; Wu et al. 2011). There are two arguments on the origin of channels. One is gravity flow origin, which claims that the channels are caused by the incision of turbidity current and mass transported flow due to slumped delta front or foreset beds of slope (Yao et al. 2008; Xie et al. 2011); the other is tractive current origin which claims that the hydrodynamic force is derived from bottom current or internal tidal action (Zhu et al. 2007, 2008; Shao et al. 2010).

A recent research shows that the clastic rocks in the axial channel came from multiple provenance systems including river system from the western and southern part of the Hainan Uplift (Wang and Xiangding 2004; Wang et al. 2014), the Red River, the Ma River, the Lan River systems from the northern part of the Kon Tum Uplift, and the Qiupen River system from the central part of the Kon Tum Uplift (Yuan et al. 2010a, b; Van Hoang et al. 2010). Rivers in western and southern part of the Hainan Uplift come primarily from the Wuzhi Mountain area, where there are widespread magmatic rocks. Multiple sedimentary rocks (clastic rock and limestone), magmatic rocks, and a few Archaeozoic-Proterozoic metamorphic rocks are exposed in the Red River area of northern Kon Tum Uplift, and protoliths mainly consist of sedimentary rocks. Sedimentary rocks, magmatic rocks, and metamorphic rocks are distributed evenly in the Qiupen River area in the central part of Kon Tum Uplift. The comparison of rock compositions shows that the deposits in the early channels primarily came from 
river systems from western and southern Hainan Uplift, while clastic sediments carried by the Qiupen River from the central part of Kon Tum Uplift may have a significant influence on the deposits of the later channels. Besides, sediments from the other river systems also mixed in two stages of channel sandstone (Fig. 2).

\section{Sedimentary characteristics of Huangliu channel reservoirs}

The spatial distribution of early channels is unstable with high curvature and frequent incision. The early channels mainly developed at the bottom of Huangliu Formation. The slope gradient was gentle so that the gravity fluid flow is absent, and thus their lateral switches are frequent. Consequently, all of the early channels converged to the east. The later channels had larger scale with stable spatial distribution, and eventually converged to one central canyon in the Qiongdongnan Basin. Their straight geometries indicate that the terrain of the Qiongdongnan Basin was low in the west with large slope gradient. Furthermore, the terrigenous clastic sediments carried by the Qiupen river flowed down from the Kon Tum Uplift were accumulated in the Ledong Sag, and then moved eastward, so the abundant sediment supply from the west increased the topographic gradient of the eastern Qiongdongnan Basin, accelerating effect of gravity fluid flow which led to the formation of deep straight restrictive canyon. The restrictive terrain caused greater canyon erosion, and the scale of canyon increased greatly with decreased sinuosity. The extensive canyon erosion process was continuous till the sea level rose to a certain point, and then the canyon started to accept depositions. Large-scale canyon in negative landform facilitated multistage depositions of sandstone. The stacking thickness of channel sandstones could be more than $400 \mathrm{~m}$.

The lithology of the two stages of axial channels sandstone is chiefly gray massive fine sandstone, which features smooth low-amplitude micro-serrated box gamma ray curve (Fig. 3), and the shale content is generally below $10 \%$ which also reflects the intense paleo-hydrodynamic environment. The single-layer thickness of channel sandstone is stable with a general thickness of $20-30 \mathrm{~m}$. The maximum single-layer thickness of drilled sandstone is $50 \mathrm{~m}$. The quartz content in channel sandstone is $70 \%$ on average with high compositional maturity. The separation of sandstone is medium to fine and the sphericity is from sub-angular to sub-round. The compositional maturity

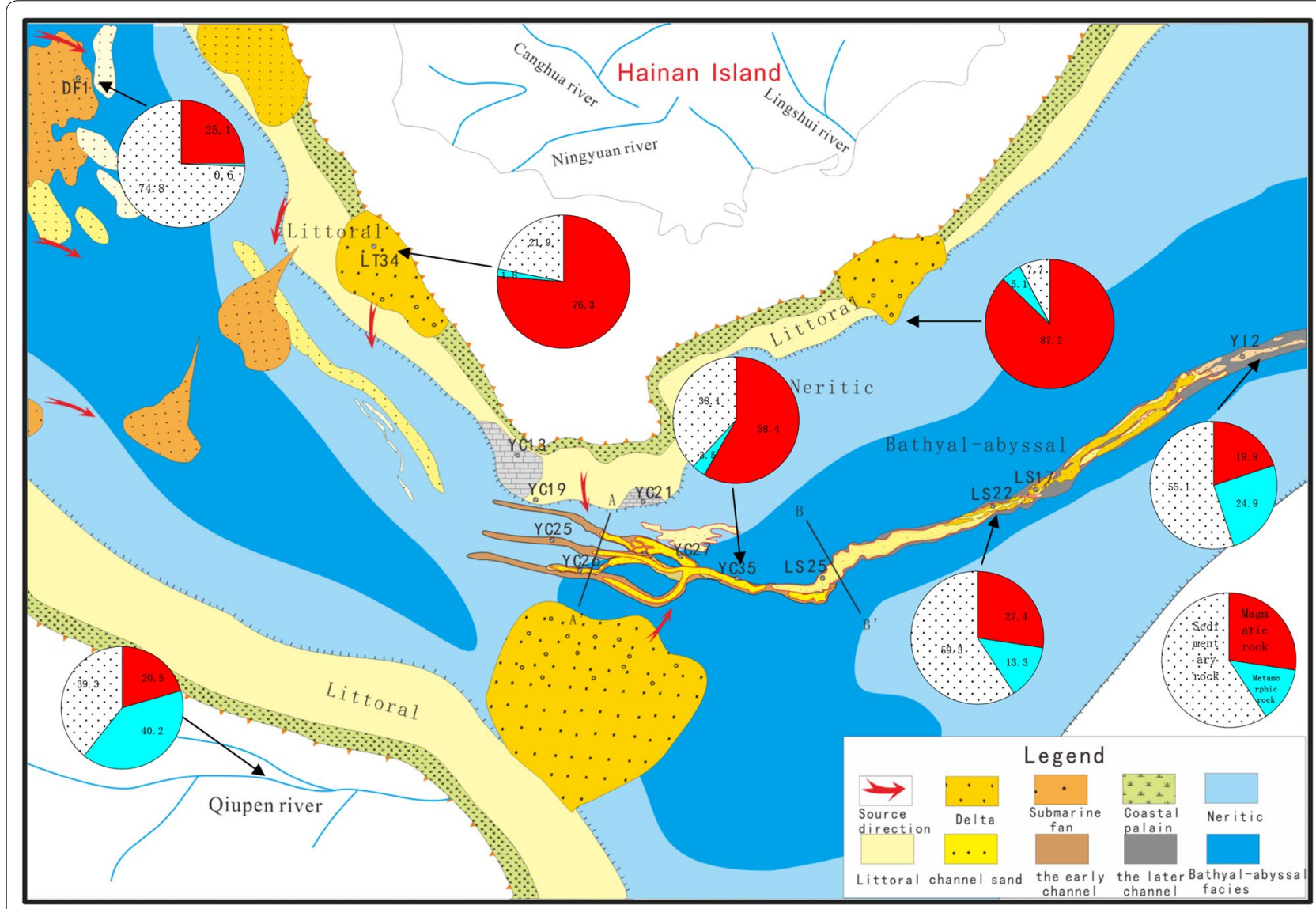

Fig. 2 Sedimentary facies and rock compositions of the Huangliu Formation in northern South China Sea 


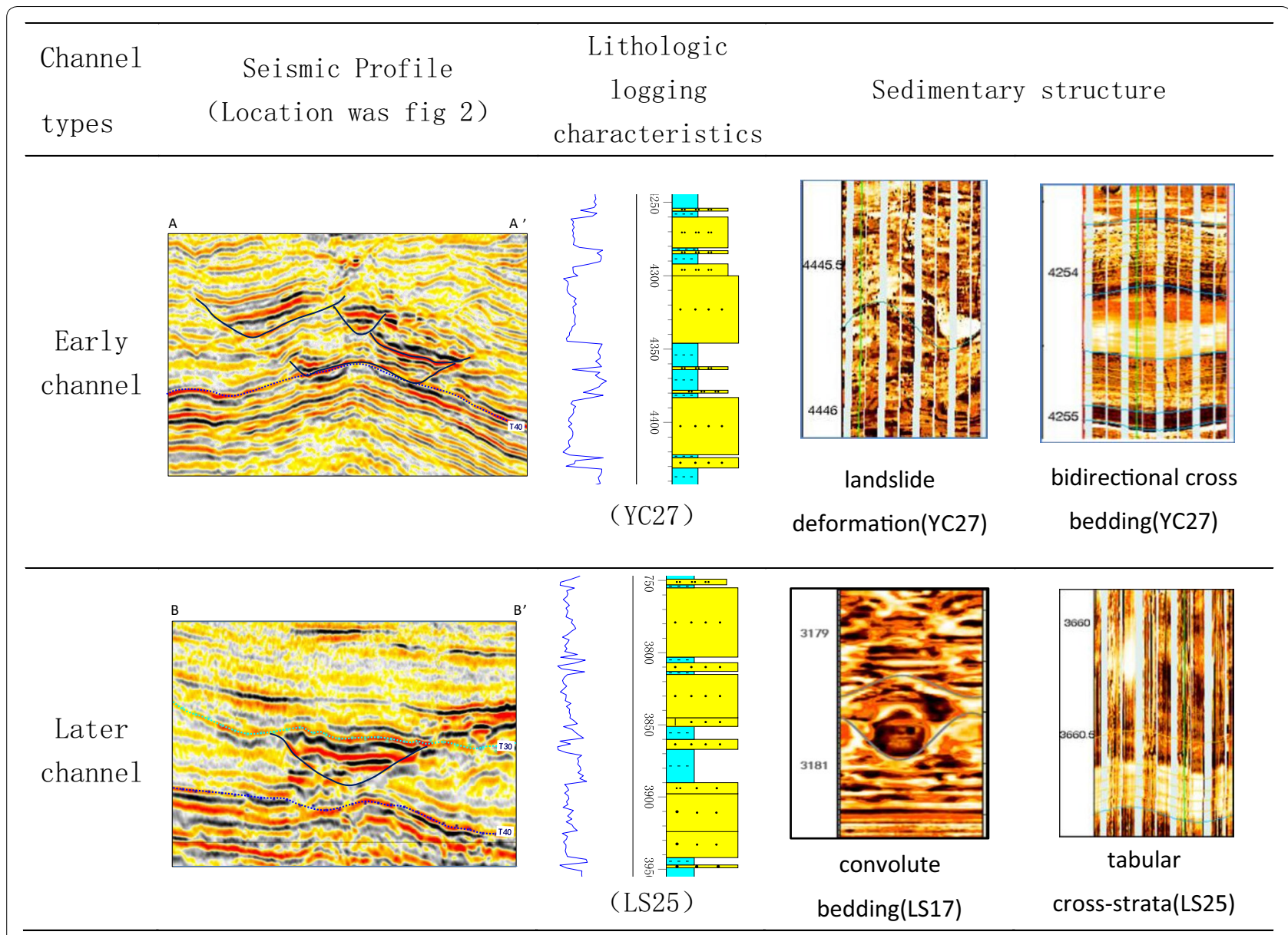

Fig. 3 The sedimentary characteristics of two-stage channels in the Huangliu Formation, Qiongdongnan Basin

of channel sandstones goes up from the west to the east, which implies the direction of sediment transportation is from the west. The grain-size probability curve of channel sandstone shows the characteristics of two stages, and sampling points in C-M figure are parallel to C-M baseline which indicates that the intense hydrodynamic environment and the influence of tractive current during the depositional processes. Typical gravity fluid flow sedimentary structures such as convolute bedding, load structure, graded bedding, slump, fining upward grading, and erosional basal surface could be observed under the core description and FMI image interpretation. Massive bedding and normal graded bed are common with rare cross-bedding and argillaceous stripes. Moreover, some sedimentary structures, such as wavy bedding, flaser bedding, bimodal cross-bedding, and low-angle bedding often appear in channel sandstone, especially the double mudstone laminae caused by bidirectional flow, which demonstrates that the channel sandstone deposits were reworked by bottom current such as internal tide. It is worth noting the occurrence of bimodal sedimentary structures in deep water turbidites, which is widely interpreted as internal tidal action (Rattry 1960; Laird 1972; $\mathrm{He}$ and Gaozhenzhong 1998). Internal tide is one kind of water movement produced by the difference in vertical water density, which has the same period with surface tide and generally develops in the regions with acute changing topography such as submarine canyon or slope break belt. As a type of deep water tractive current, internal tide often interacts with gravity fluid flow and retransfers or remolds the previous turbidites such as submarine fan and turbidite channel (Tong et al. 2007). Therefore, the channel reservoirs are composed of gravity fluid flow deposits and reworked by internal-tide bottom current. The internal-tide sediments occur mainly in early channel sandstone, and the gravity fluid flow sediments play a dominant role in later channels sandstone. The reworking bottom current washed shale content away from sandstone, so that the mean permeability of the axial channels sandstone reservoir could reach up to $30 \mathrm{md}$. Compared with other common gravity fluid flow reservoir in the 
Qiongdongnan Basin, the axial channel reservoir is characterized by low shale content and clean sandstone.

\section{Sedimentary characteristics of submarine fan reservoirs in the Meishan Formation}

Different from the Huangliu Formation axial channel sandstone, drilling results indicate that the heavy mineral assemblages of the Meishan Formation in the Ledong and Lingshui sags display the magmatic components characteristics. It means that the provenance of the Meishan Formation sediments was mainly from the Ningyuan River and Lingshui River, which originated from the southwestern Wuzhi Mountain in the Hainan uplift. Because of regional sea level falling sharply in $13.8 \mathrm{Ma}$ (Pang et al. 2005), terrigenous clastic sediments carried by these rivers were transported from the northern slope break of the Ledong and Lingshui sags, resulting in submarine fan deposits (Xie et al. 2016). In addition, the southwestern slope break of the Ledong sag might be another source area of the Meishan submarine fan (Zuo et al. 2015), although there is not enough seismic data to confirm it.

Influenced by the location of shelf-margin delta, during falling sea level, ancient submarine topography, and bottom current reworking effect, submarine fan complexes in the Ledong and Lingshui sags exhibit various sedimentary patterns and geometries. These sedimentary patterns of submarine fans finally determine the development scale of reservoirs and physical properties. According to their locations, geometries, and sedimentary characteristics, the submarine fans in the Meishan Formation could be classified into three types (Figs. 4, 5, 6): The first one is slope channelized fan, which is located at the slope or

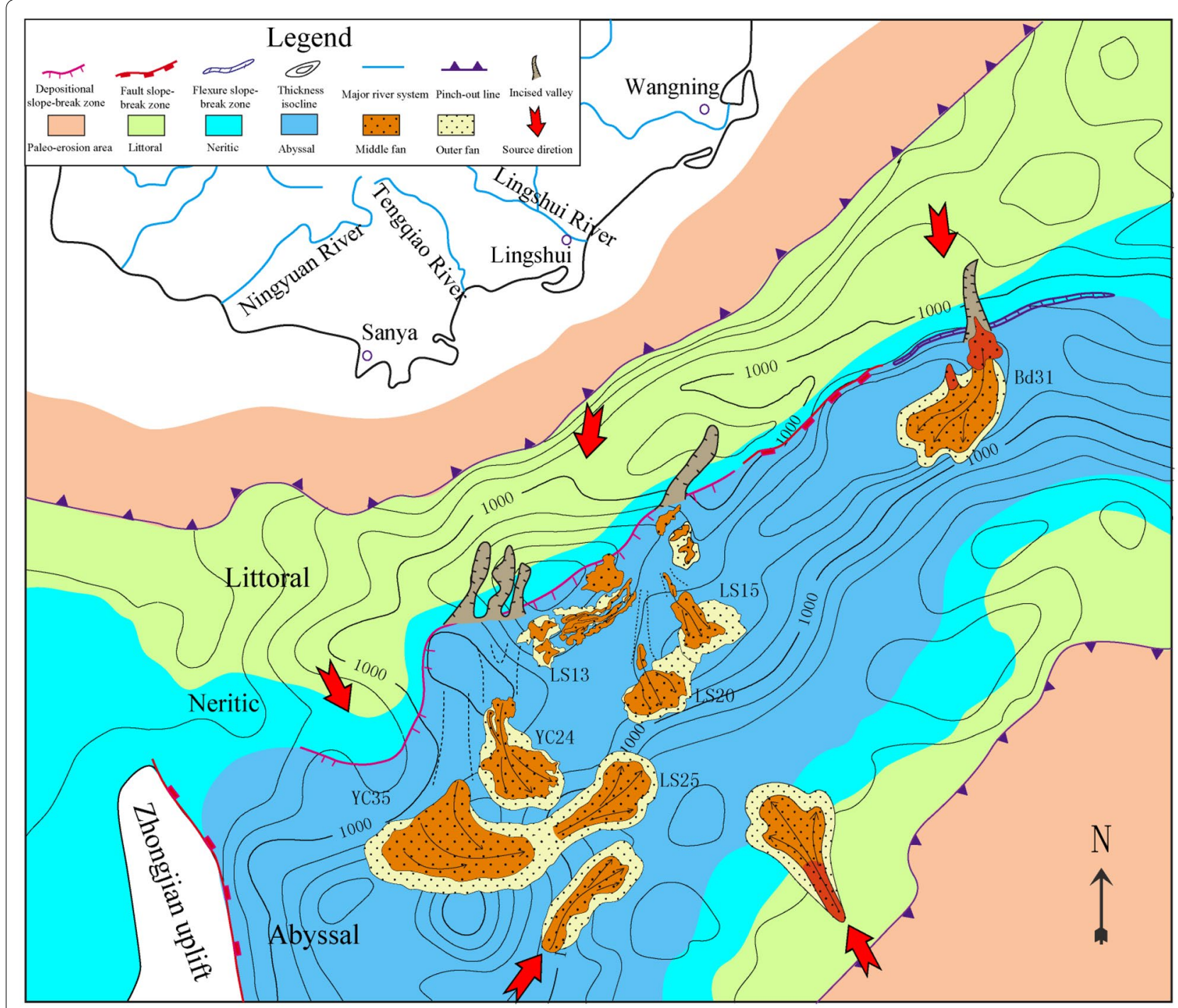

Fig. 4 Sedimentary facies of the Meishan Formation in the Ledong and Lingshui sags, Qiongdongnan Basin 


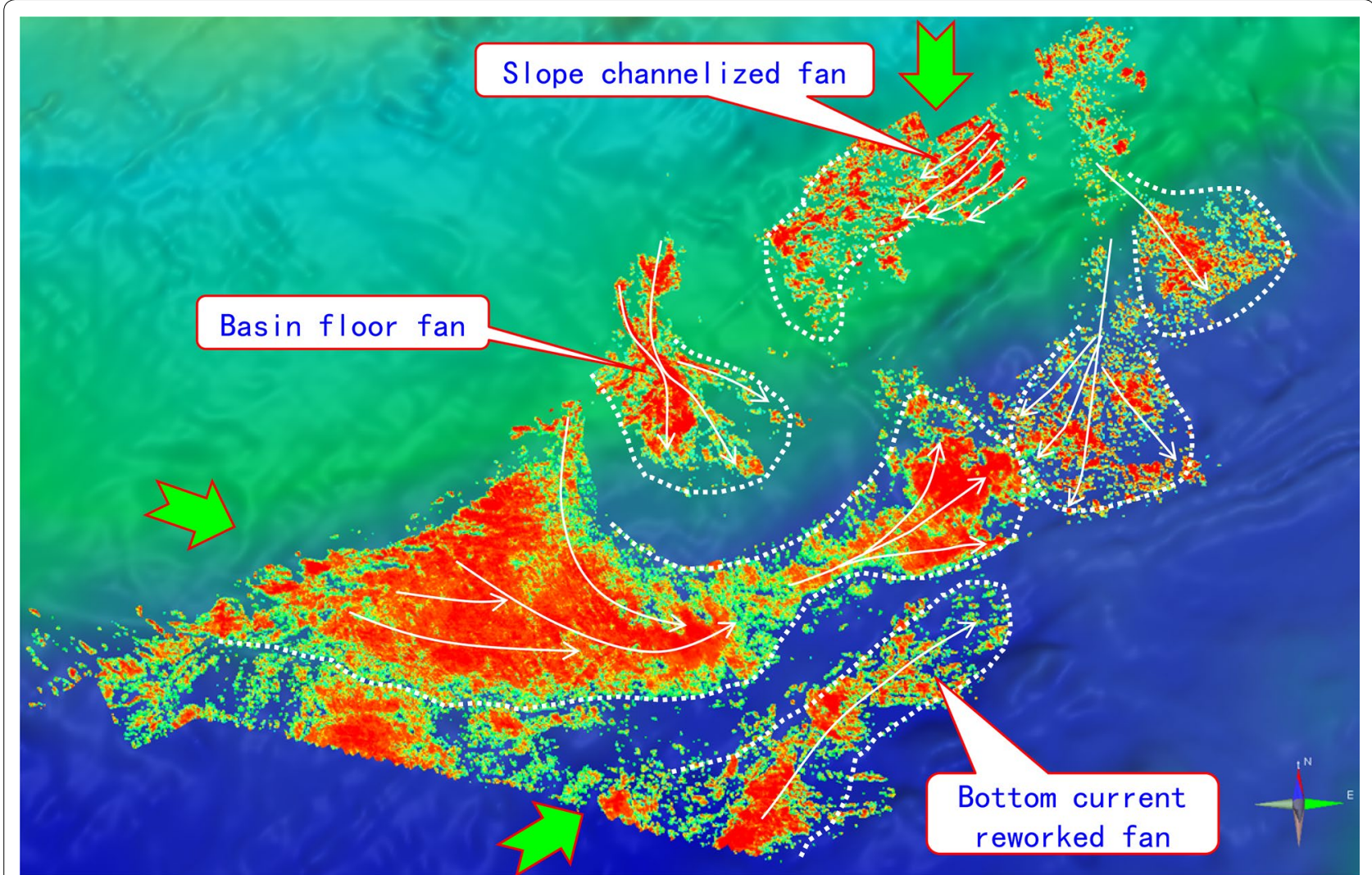

Fig. 5 The distribution and types of submarine fans of the Meishan Formation in the Ledong and Lingshui sags in work area A, Qiongdongnan Basin (location is shown in Fig. 1)

steep slope toe. It is formed in the lower Meishan Formation, and has the characteristics of unstable depositional center and rapid lateral switch with a small thickness $(<40 \mathrm{~m})$. Three sedimentary units can be further divided in the slope channelized fan: main channel, channel margin, and front lobe. The main channels are narrow and straight with few branch channels. Because of the fast lateral switch and transient depositional processes, the reservoir sandstones predominantly are spread along the main channels (Fig. 7). Since the incision of main channels is shallow, the front lobe usually appears in a strip shape with limited area. The slump deposits developed in steep slope toe owing to high stratigraphic dip angle and the slope channelized fan reservoir was often reconstructed by them. Therefore, the reservoir of front lobe has the characteristics of high shale content, while the "clean" fine and silt sandstone reservoirs mostly are distributed in main channels, and gamma ray curve characteristic has a micro-serrated box-shaped feature. Sedimentary structures of the main channel include parallel beddings, graded beddings, as well as erosional basal surfaces, which could be interpreted as typical turbidites.
The second type of submarine fan is basin floor fan. Due to differential subsidence, there was no typical Miocene abyssal plain developed in the Qingdongnan Basin. Conversely, many wide low-lying areas existed from slope toe to the center of the Ledong and Lingshui sags, making it easy to form stable superposed gravity fluid flow deposits. The basin floor fans have classical fan shapes with several sedimentary units, such as inner fan feeding channel, branch channel, overbank-natural, bank front lobe, and so on. Their feeder channels locate in the slope toe along NW-SE direction. There are two short-straight feeder channels developing successively, which extend about $10 \mathrm{~km}$ long and $1 \mathrm{~km}$ wide. The ends of channels converge and overlap each other, indicating a stable environment in their depositional center. The seismic profiles present the features of medium-strong amplitude reflection and continuous seismic events, and the V-shaped incisions can be seen on underlying stratums. In addition, a few natural levees are developed on the margin of channels. Drilling results reveal that the fillings in the channels are moderate-coarse sandstone with poorer sorting and box-shaped logs. 


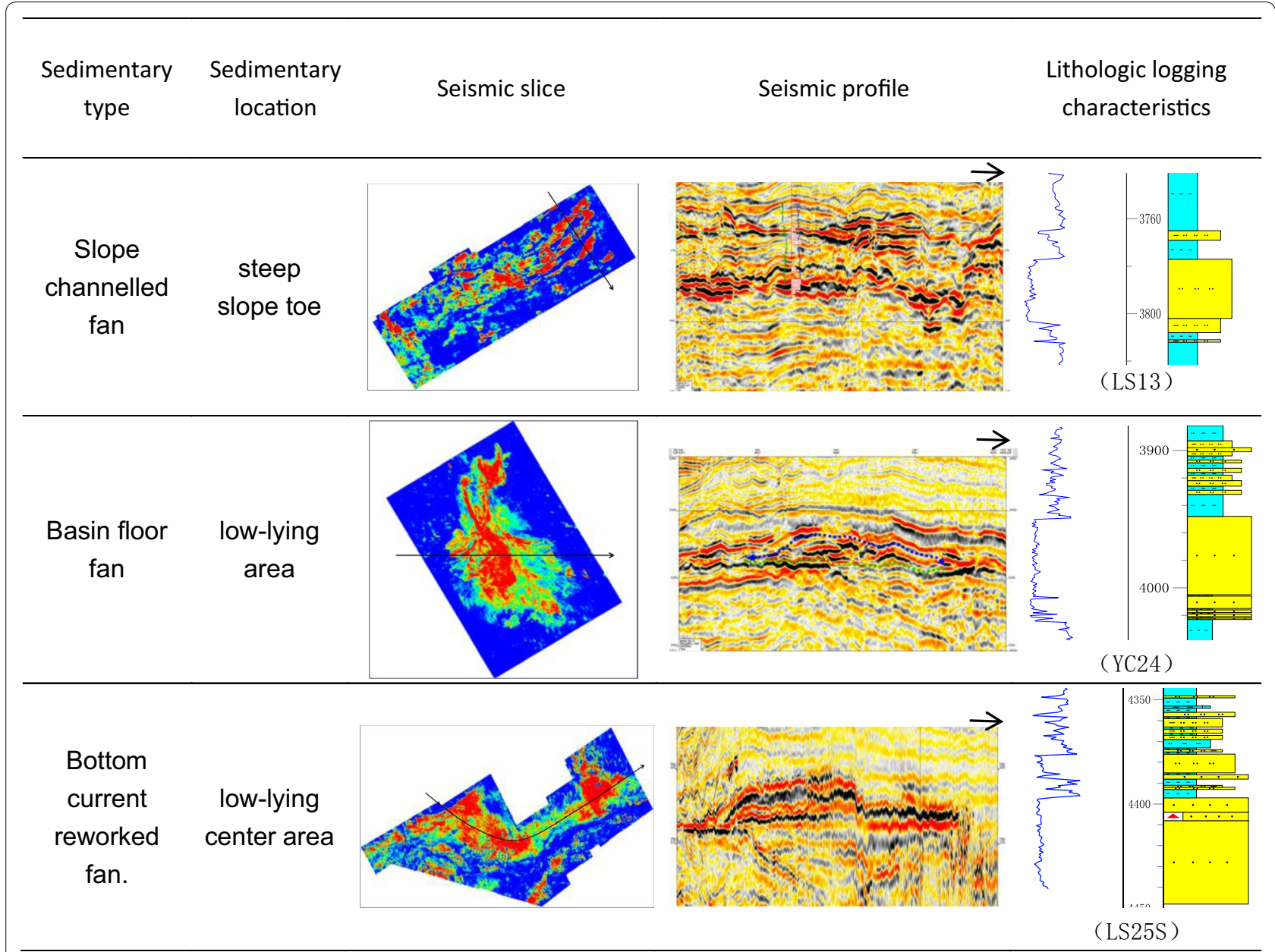

Fig. 6 Characteristics of submarines fans of the Meishan Formation in the Qiongdongnan Basin

The third type of the Meishan submarine fans is the fan reworked by bottom currents, which are distributed in the central low-lying area in the Ledong and Lingshui sags. Sand-body develops along the axis of the basin. Moreover, the sand-body thickness becomes thinner abruptly, comparing to the adjacent basin floor fan, and the seismic profiles show low-amplitude incised characteristics in sandstone bottom interface. All the features above illustrate that the effect of bottom current paralleling with the slope existed in the basin center. It is speculated that the bottom current occur when channelizing processes of submarine fan began. The sandstone reworked by bottom currents has better sorting, homogeneity, and permeability than those of the other two types of fans. Drilling results prove that the submarine fans reworked by bottom currents have box-shaped characteristics of gamma ray curve. The sedimentary features mostly include massive bedding and its lithology is well-sorted thick fine sandstone. The channels have weak erosion with medium-strong amplitude reflection shown in seismic profiles.

\section{Origin and types of traps}

Two kinds of reservoirs discussed above formed four types of traps through differential deposition and subsidence (Fig. 8). The deposition played a leading role in the trap formation with deposition pinch out and erosion action. The two-stage Huangliu channels have different trap forming modes and types. The early channels switched so frequently that obsoleting channels were easy to form lithological traps on account of sand-body pinching out (Fig. 8a), while the later channels formed "sandbank-like" or "anticline-like" stratigraphic traps as the late hydrodynamic force could erode and rework sandstone easily in restrictive canyon (Fig. 8b). Furthermore, because of channel sandstones extending along the axis of basin and the influence of differential subsidence in sags, deeper underlying formation formed a series of 


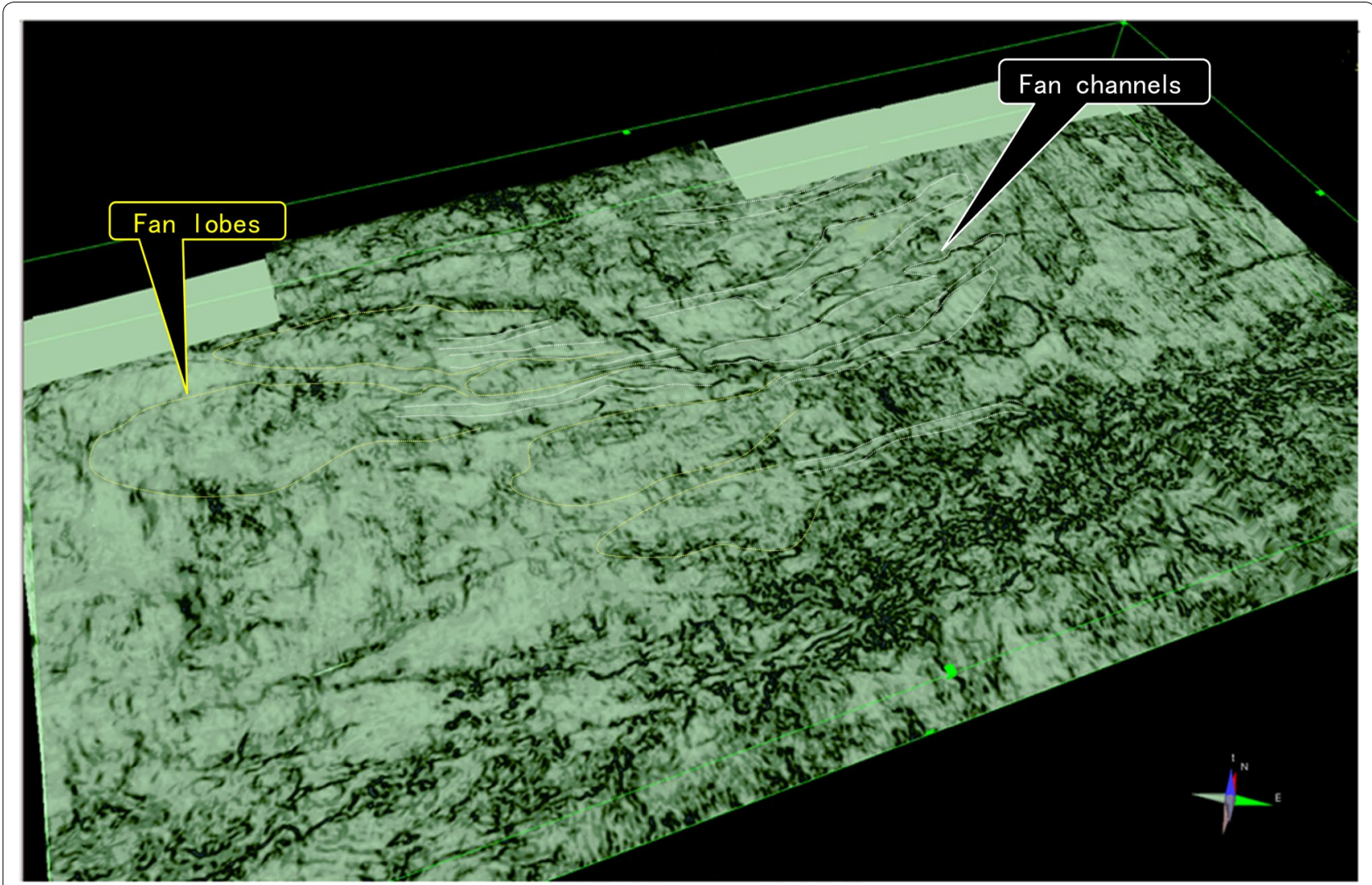

Fig. 7 The time-slice showing channelized submarine fan in slope area of the Lingshui sag in work area B, Qiongdoangnan Basin (location is shown in Fig. 1)
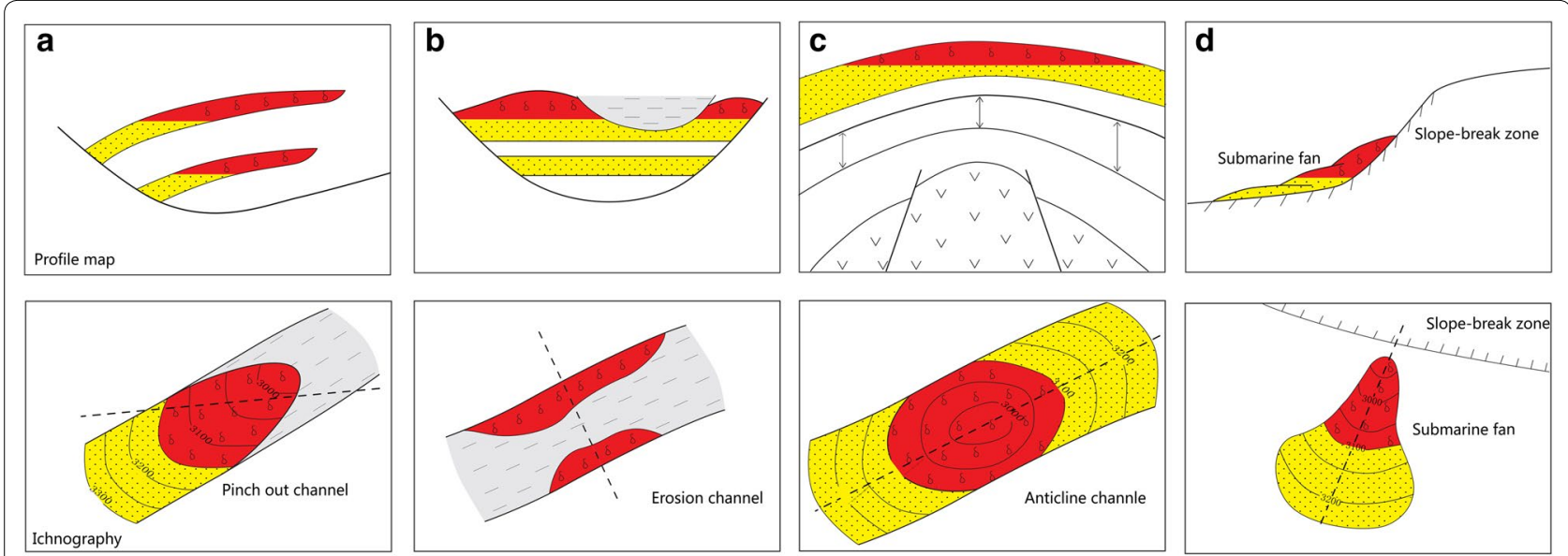

Legend

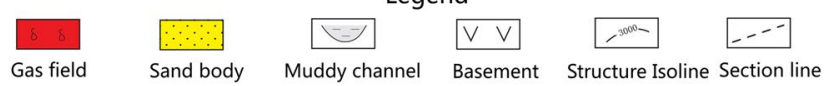

Fig. 8 The types and characteristics of lithology-stratigraphic traps in the Ledong and Lingshui sags, Qiongdongnan Basin 
wide gentle nose-structures which stretched into sags center from south to north and crossed with E-W directional axis channels, so lithology-stratigraphic traps with structural setting were formed (Fig. 8c).

The trap formation for Meishan submarine fans is mainly caused by the deposition pinching out (Fig. 8d). As the entire basin subsided continuously in Neocene, the later differential regional tectonic subsidence affected the structural height. In Pliocene and Pleistocene, the subsidence centers transferred to the Ledong sag gradually, which led to terrain reversal, so the pinch out position of fans reworked by bottom currents became the highpoint of trap formation. Overall, deposition pinching out is the main controlled factor of submarine fan traps.

\section{Hydrocarbon migration under fractured system induced by overpressure Gas component}

Gas components in the Ledong and Lingshui sags are mainly hydrocarbon. Methane content is over $90 \%$ generally, and the content of $\mathrm{C}_{2+}$ is low. It can be classified as dry gas with a gas dry coefficient of over 0.9 . The carbon isotope value of hydrocarbon is $-40 \% 0>\delta^{13} \mathrm{C}_{1}>-34 \%$, $-26 \% 0>\delta^{13} C_{2}>-22 \%$ (Fig. 9). These gas component features and values of $\delta^{13} \mathrm{C}_{1}$ and $\delta^{13} \mathrm{C}_{2}$ are similar to those of Yacheng 13-1 gas field (He et al. 2000), belonging to high maturity gas from the Yacheng Formation source rock in the Ledong and Lingshui sags.

According to the relationship between gas maturity and methane $\delta^{13} \mathrm{C}_{1}$, the gas maturity of entirely channel sandstone presents a tendency that the maturity increases from the east to the west, so it can be inferred that gas migrated from west to east. However, the maturity tendency of LS17 gas field in the east is reversed, which means that the strip-like channel traps across the entire Ledong and Lingshui sags were charged by gas with different maturities.

\section{Gas migration under fractured system induced by overpressure}

Except for the reactivation of Fault No. 2 in the north slope of the Lingshui sag, all other fault activities were absent in the Ledong and Lingshui sags in Neocene, and thus oil and gas mainly migrated vertically through the fractures induced by overpressure.

Overpressure played an important role in hydrocarbon migration. According to the statistics of formation fracture test data of wells in the Qiongdongnan Basin, when pore fluid pressure coefficient is over 2.0 (Fig. 10), regional scaled fracture network starts to appear. Driven by buoyancy and overpressure, gas generated from the deeper formation can migrate through the fractured network. This process was lasting as the fluid pressure in the Ledong and Lingshui formation increased continuously after 10.5 Ma. The pressure kept enhancing until fractures opened and provided power for energy release. In addition to overpressure, flexing action could also lead to the formation of fractures in the area where differential subsidence occurred. This has been becoming an important hydrocarbon exploration area, because it has

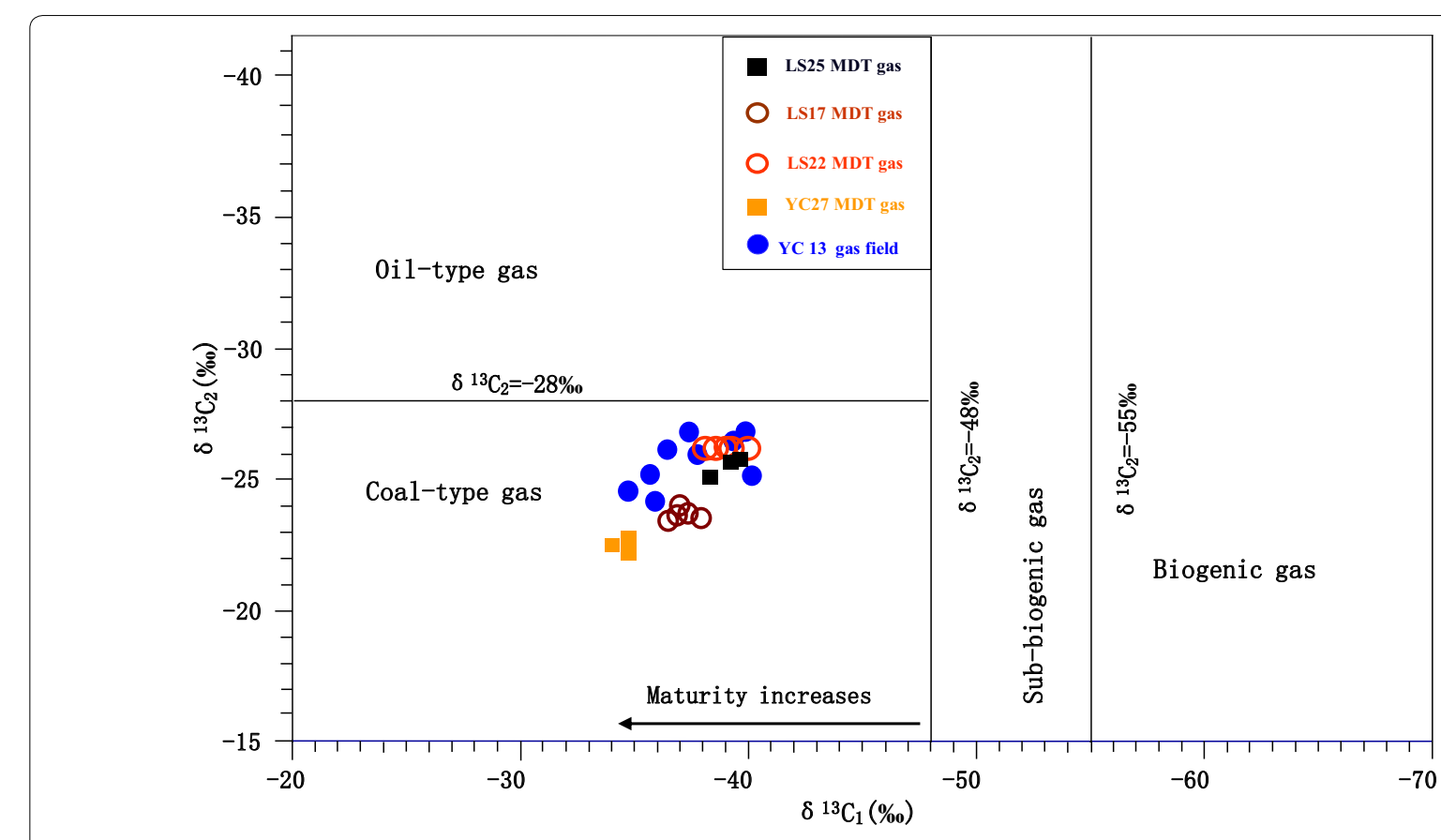

Fig. 9 The relationship between methane and ethane isotopes and gas genetic types in western Qiongdongnan Basin 

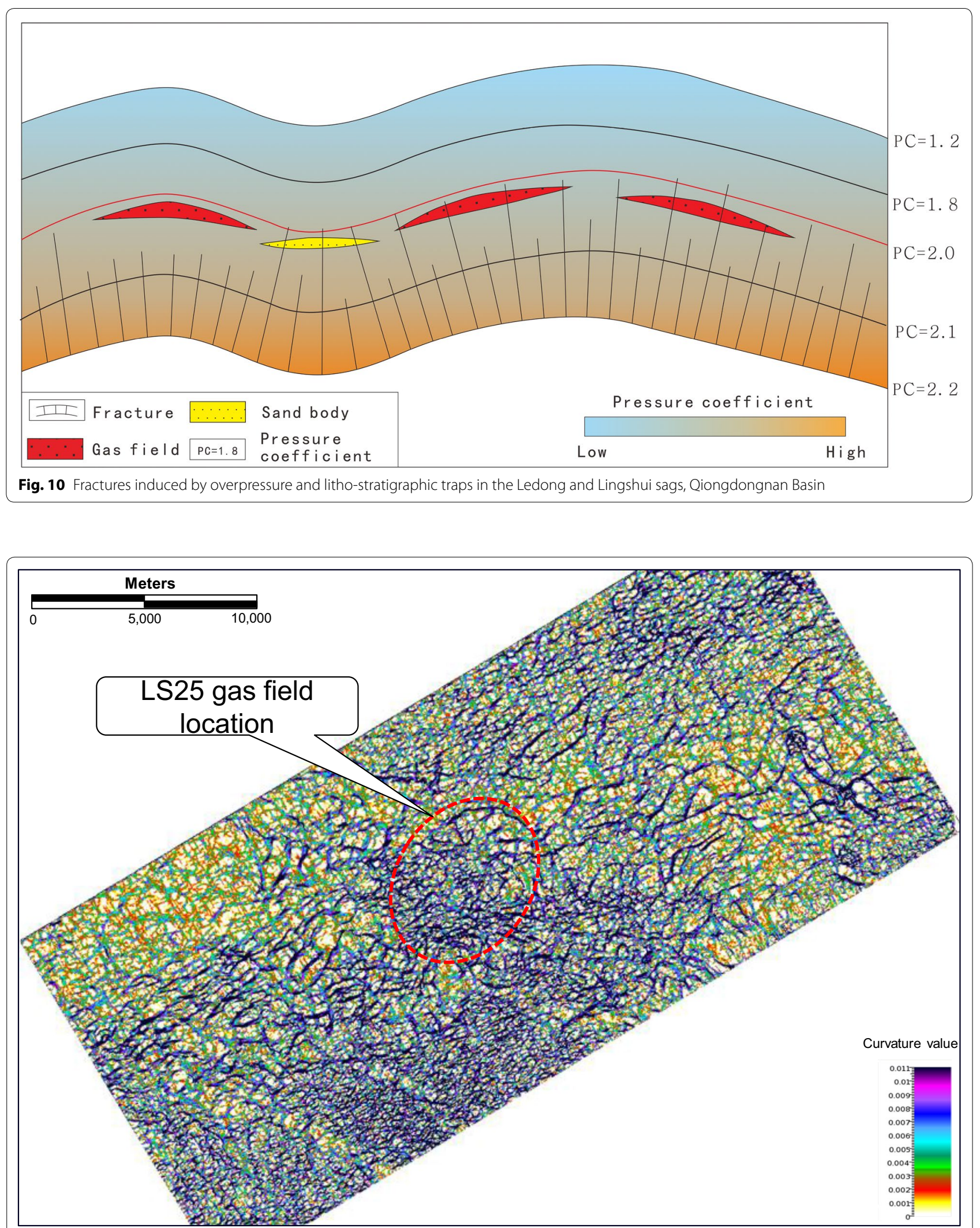

Fig. 11 The most positive curvature seismic attributes in LS25 gas field showing the fractured network for hydrocarbon migration and accumulation in work area C (location is shown in Fig. 1) 
a higher fracture density and is easier to form the lithology-stratigraphic traps with structural system. LS25 gas field can be taken as an example, which is located exactly on the nose-structure with substantial fractures below, which was formed due to the Lingnan uplift stretching into the Ledong sag (Fig. 11). The main reservoir of LS25 gas field is the later channel sandstone and its trap is distributed along the long axis of channel with both strip and "anticline-like" shape, which belongs to lithostratigraphic trap. The reservoir is composed by many sets of thick sandstone and its total thickness can be up to $20 \mathrm{~m}$. The gas-bearing area mainly concentrates in structural scope. The lithology is mainly fine sandstone with low shale content. Porosity are ranged between 13 and $20 \%$. Gas components is mainly methane with high gas dry coefficient and the carbon isotope values are $-40 \% 0>\delta^{13} C_{1}>-36 \%$, $-26 \%$ o $>\delta^{13} C_{2}>-24 \%$, respectively, which is consistent with typical coal-type gas generated by the early Oligocene Yacheng formation.

\section{Conclusion}

Controlled by early Oligocene pull-apart strike slip of the Red River Fault in, the Yacheng Formation source rock in the Ledong and Lingshui sags were developed in a large scale with enormous resource potential. Middlelate Miocene abundant terrestrial sediments contributed to the formation of reservoirs, including the Huangliu axial channel sandstone and the Meishan submarine fan sandstone, which resulted in four types of lithologystratigraphic traps under the actions of deposition and differential subsidence. Regional fractured network in deeper formation below these traps were induced by hydrothermal and hydrocarbon-generating overpressure, and connected source rock to reservoirs; therefore, gas could migrate to lithology-stratigraphic traps driven by buoyance and overpressure to be accumulated finally. The genesis of Miocene lithologic trap and hydrocarbon accumulation in the Qiongdongnan Basin have been revealed by several recent discoveries, and it will contribute to further hydrocarbon exploration in northern South China Sea.

\section{Authors' contributions}

CF designed the research. TJ and KL drew the relevant figures with JT. All authors discuss the obtained results and drafted. All authors read and approved the final manuscript.

\section{Author details}

1 Zhanjiang Branch of CNOOC Ltd. Zhanjiang 524057, Guangdong, China. 2 Key Laboratory of Tectonics and Petroleum Resources of Ministry of Education, China University of Geosciences, Wuhan 430074, China.

\section{Acknowledgements}

The authors greatly appreciate Mr. Song Peng and Mr. Zhou Fan for their sincere helps. The authors are grateful also to Western South China Sea Laboratory for providing some experimental datum.
Competing interests

The authors declare that they have no competing interests.

Availability of data and materials

The experimental data referred in the paper are available from the corresponding author on reasonable request.

\section{Ethics approval and consent to participate}

Not applicable.

\section{Funding}

This study was supported by the China National Science and Technology Major Project (2016ZX05024-005).

\section{Publisher's Note}

Springer Nature remains neutral with regard to jurisdictional claims in published maps and institutional affiliations.

Received: 3 September 2017 Accepted: 23 April 2018

Published online: 30 April 2018

\section{References}

Antbreh AA, Krastel S (2006) Morphology seismic characteristics and development of Cap Timiris Canyon, offshore Mauritania: a newly discovered canyon preserved-off a major arid climatic region. Marine Petrol Geol 23(1):37-59

Chen W, Liqi Q, Wang Y (1996) Miocene diachronic uplift along the Ailao Mountains-Red River left-lateral strike-slip shear zone. Geol Rev 42(5):385-390 (in Chinese)

Gong ZS, Li ST (2004) Dynamic research of oil and gas accumulation in northern marginal basins of South China Sea. Science in China Press, Beijing, pp 46-60 (in Chinese)

He Y, Gaozhenzhong (1998) Characterization and identification of the internal tide and wave deposits. Sci Bull 43(9):903-908 (in Chinese with English abstract)

He J, Weihuang C, Mingxing L (2000) Genetic types of natural gas and source rocks in Ying-Qiong basin. China Offshore Oil Gas (Geology) 4(6):400-401 (in Chinese with English abstract)

He Y, Xie X, Lu Y (2011) Architecture and characteristics of mass transport deposits(MTDs) in Qiongdongnan Basin in Northern South China Sea. Earth Sci 36(5):905-913 (in Chinese with English abstract)

Laird MG (1972) Sedimentology of the Greenland group of the Paparoa Range, west coast, South Island, New Zealand. NZ J Geol Geophys 15:372-393

Lei C, Jianye R, Xushen L (2011) Structural characteristics and petroleum exploration potential in the deep-water area of the Qiongdongnan Basin, South China Sea. Petrol Explor Develop 38(5):560-569 (in Chinese with English abstract)

Li W, Zhang Z, Youchuan LI (2011) Geochemical characteristics and hydrocarbon generation of paleogene oligocene source rocks in Qiongdongnan Basin. Nat Gas Geosci 22(4):700-708 (in Chinese with English abstract)

Lin C, Jingyan L, Shixiang C (2011a) Sedimentation and evolution background old large incised channel and submarine gravity flow system in Ying-Qiong basin. Chin Sci Bull 46(1):69-72 (in Chinese with English abstract)

Lin W, Jiaren Y, Chuang L (2011 b) Geothermal and maturation histories modeling of the source rocks in the Ledong Sag, Qiongdongnan Basin. Geol Sci Technol Inform 30(6):110-115 (in Chinese with English abstract)

Mi L, Dongdong W, Zengxue L (2010) High-resolution sequence stratigraphic framework and coal-forming features in Yacheng Formation of Qiongdongnan Basin. Acta Petrol Sinica 31(4):534-541 (in Chinese with English abstract)

Pang X, Chen C, Hesheng S (2005) Relative sea level changes and response of deep water systems in Pearl River Mouth Basin, South China Sea. Earth Sci Front 13(3):167-177 (in Chinese with English abstract)

Pettingill HS, Weimer P (2002) Worldwide deep water exploration and production: past, present, and future. Lead Edge 21(4):371-376

Rattry M (1960) On the coastal generation of internal tide. Tellus 12:54-62 
Shao L, Li A, Guoxuan W (2010) Evolution of sedimentary environment and provenance in Qiongdongnan Basin in the northern South China Sea. Acta Petrolei Sinica 31(4):548-552 (in Chinese with English abstract)

Su M, Xie X, Wang Z (2013) Sedimentary evolution of the central canyon system in Qiongdongnan Basin, northern South China Sea. Acta Petrolei Sinica 34(3):467-478 (in Chinese with English abstract)

Tapponnier P, Lacassin R, Leloup PH et al (1990) The AilaoShan-Red River metamorphic belt tertiary left lateral shear between Indochina and South China. Nature 243:431-437

Tong Y, Youbin H, Guanghui Z (2007) Classification of internal-wave and internal-tide deposits in deep water and significance to petroleum prospecting. Marine Origin Petrol Geol 12(2):39-44 (in Chinese with English abstract)

Van Hoang L, Chift PD, Schwab AM (2010) Large-scale erosional response of SE Asia to monsoon evolution restricted from sedimentary records of the Song Hong-Yinggehai and Qiongdongnan Basin, South China Sea. Geol Soc 342:219-244

Wang Q, Xiangding H (2004) Hainan Province office of local chronicles, the records of geology and mineral resources of Hainan Province. Nanhai Publishing Company, Shanghai (in Chinese)

Wang X, XU Q, Li D (2011) The Red River Fan of the Late Miocene in Northwestward South China Sea. Chin Sci Bull 56:781-787 (in Chinese with English abstract)

Wang C, Xinquan L, Chuanxin T (2014) Characteristics and geological implications of heavy minerals from seven rivers in adjacent areas of northeastern Yinggehai Basin. Acta Sedimentol Sin 32(2):228-237 (in Chinese with English abstract)

Wu S, Qin Y (2009) The research of deepwater depositional system in the northern south China sea. Acta Sedimentol Sin 27(5):922-930 (in Chinese with English abstract)

Wu J, Wang Y, Yingmin Q (2011) A depositional model of submarine canyons in Baiyun Sag, Pearl River Mouth Basin. Marine Geol Front 27(8):26-31 (in Chinese with English abstract)

Xie Y, Tong C (2011) Condition and gas polling modes of natural gas accumulation in the Yacheng 13-1 gas field. Nat Gas Ind 31(8):1-5 (in Chinese with English abstract)
Xie XN, Muller RD, Li ST (2006) Origin of anomalous subsidence along the northern South China Sea margin and its relationship to dynamic topography. Marine Petrol Geol 23(7):745-765

Xie X, Zhang C, Jianye Ren (2011) Effects of distinct tectonic evolutions on hydrocarbon accumulation in northern southern continental Marginal Basins of South China Sea. Chin J Geophys 54(23):3280-3290 (in Chinese with English abstract)

Xie Y, Fan C, Zou J (2016) Sedimentary features and controlling factors of the gravity flows in submarine fan of middle miocene in the Qiongdongnan Basin. Nat Gas Geosci 27(2):220-228 (in Chinese with English abstract)

Xu H, Cai D, Sun Z (2012) Filling characters of central submarine canyon of Qiongdongnan Basin and its significance of petroleum geology. Acta Geol Sin 86(4):641-650 (in Chinese with English abstract)

Yao G, Yuan S, Wu S (2008) The double provenance supply depositional model and its exploration prospect in the deepwater of Qiongdongnan Basin. Petrol Explorat Dev 35(6):685-691 (in Chinese with English abstract)

Yuan W, Wu SG, Yao G (2010a) The controlling factors analysis of Qiongdongnan slope deepwater channels and its significance to the hydrocarbon exploration. Marine Geol Quat Geol 30(2):61-66 (in Chinese with English abstract)

Yuan S, Wu S, Zhao Z, Xu F (2010b) Deepwater sediment transportation models for Northern South China Sea Slopes. Marine Geol Quat Geol 30(4):39-48 (in Chinese with English abstract)

Zhao M, Zhang X, Ji L (2010) Characteristics of tectonic evolution in the Qiongdongnan Basin and brief discussion about its controlling on reservoirs. Nat Gas Geoscience 21(3):494-502 (in Chinese with English abstract)

Zhu W et al (2007) The gas geology in northern continental marginal Basin of South China Sea. Petroleum Industry Press, Beijing, pp 8-52 (in Chinese)

Zhu W, Zhang G, Gao L (2008) Geological characteristics and exploration objectives of hydrocarbons in the northern continental margin basin of South China Sea. Acta Geol Sin 29(1):1-9 (in Chinese with English abstract)

Zuo Q, Zhang D, He W (2015) Provenance analysis of Huangliu Formation of the central canyon system in the deep water area of the Qiongdongnan Basin. J Haiyang Xuebao 37(5):15-23 (in Chinese with English abstract)

\section{Submit your manuscript to a SpringerOpen ${ }^{\circ}$ journal and benefit from:}

- Convenient online submission

- Rigorous peer review

- Open access: articles freely available online

- High visibility within the field

- Retaining the copyright to your article

Submit your next manuscript at $\boldsymbol{\nabla}$ springeropen.com 